\title{
Translator Trainees' Reading Literacy, Problem Solving, and Translation Skills A Comparative Study
}

\author{
Gabriella KOVÁCS
}

Sapientia Hungarian University of Transylvania, Cluj-Napoca

Department of Applied Linguistics, Târgu-Mureş

kovagabi@yahoo.com

\author{
Katalin HARANGUS \\ Sapientia Hungarian University of Transylvania, Cluj-Napoca \\ Department of Applied Social Sciences, Târgu-Mureş \\ katalin@ms.sapientia.ro
}

\begin{abstract}
Linguistic and cultural mediators, such as translators, interpreters, and language teachers, need complex and well-developed language skills in all the languages they work with. In this study, we examine the connections and correlations among the following skills: reading literacy in native language, reading literacy in foreign language, problem solving and translation. Three of these skills (reading in native and foreign language and problem solving) are evaluated on a three-level scale based on the three cognitive processes used in Programme for International Student Assessment (PISA) assessments (location of information, understanding, evaluation and reflection) (Organisation for Economic Co-operation and Development - OECD 2018). The methodology of measuring reading comprehension in native language and problem-solving skills has already been developed and applied by our research group (Pletl 2019, Harangus 2018); therefore, after assessing the foreign language reading literacy and translation skills, we will be able to analyse the translator trainees' results based on the aforementioned three-level scale and examine possible connections and correlations between the different but interrelated skills. With an interdisciplinary approach, this study concentrates on revealing the overlaps and meeting points, the spaces in between the use of these skills.
\end{abstract}

Keywords: problem solving, reading literacy, native language, foreign language, translation 


\section{Introduction}

This study presents a needs analysis and assessment, targeting a group of firstyear translation and interpretation students at Sapientia Hungarian University of Transylvania regarding the relationships and eventual correlations between their following skills: reading literacy in their native language (Hungarian), reading literacy in English as a foreign language, problem solving, and translation. Based on previous studies and our experience, considerable interdependence may be revealed among these skills due to the complexity of the processes of reading, problem solving, and translation. Three of these skills (reading in native and foreign language and problem solving) are evaluated on a three-level scale based on the three cognitive processes used in PISA assessments (location of information, understanding, evaluation and reflection).

Our target-group members attend a teacher training programme as well, which offers them the choice to become language teachers in the future. Our students' native language is Hungarian, and as future translators they train to work with three languages (Hungarian, Romanian - the official language of the country-, and English, which they have been studying as a foreign language). In their future profession, all language skills regarding the three languages (listening comprehension, reading comprehension, speaking, writing, translating, and interpreting) are essential.

The literature related to the assessed skills and the possible connections between them is abundant, but here - due to space limits - we attempt to give only a brief overview of the leading opinions related to our topic.

\section{Connections between reading literacy in native language and foreign language}

Reading in native and foreign languages may be considered basic skills to be developed in translator and teacher training, and reading skills and strategies in the native language can determine how successful the text comprehension is in foreign languages. Therefore, while developing foreign language reading skills and strategies, it may be effective to build upon previous knowledge that has been acquired while reading in one's native language. However, as Koda (2007) suggests, second language reading can be limited by certain language-specific features. The involvement of two languages means a continuous interaction between them and implies necessary adjustments in order to meet the demands imposed by each of the languages involved.

A large number of studies (e.g. Brisbois 1995, Yamashita 2002, Koda 2007, Grabe 2009, Mátyás 2010, Jiang 2011, Brevik, Olsen-Hellekjær 2016) discuss and demonstrate the importance of the experience in native language reading to 
second or foreign language reading, examining target groups of different ages from a various range of cultural, social, and ethnic background, with different second or foreign language levels, varying motivations, areas of interest, and attitudes towards reading. Several studies also examine the contribution of second or foreign language variables, such as phonological, vocabulary, morphologic, syntactic or text-structure knowledge, to reading literacy.

Cummins's (1979) "interdependence" and "threshold" hypotheses served as part of the theoretical background for some of these studies. The interdependence hypothesis states that first-language literacy skills can be transferred if learners are exposed sufficiently to a second language. On the other hand, the "threshold" hypothesis suggests that such transfer of skills is possible only after a threshold level has been reached in second language proficiency. Cummins's research targeted bilingual children, but Alderson (2000) - who also developed a threshold hypothesis where first language refers to the native language and second language to any non-native language - states that a threshold "must be crossed before first language reading ability can transfer to the second language. However, it is clear that this linguistic threshold is not absolute but must vary from task to task: the more demanding the task, the higher the linguistic threshold" (p. 39). The ideas that skills acquired in one's dominant (native) language can be transferred when developing second or foreign language skills and that language proficiency highly influences reading comprehension in second or foreign language are now widely accepted.

Transfer is a complex process, defined by Koda (2007) as the "automatic activation of well-established L1 competencies (mapping patterns) triggered by L2 input. Thus, transfer transpires regardless of learners' intent (nonvolitional) and its occurrence cannot be easily controlled (nonselective)" (p. 17). She mentions three assumptions underlying this view of transfer. "First, for transfer to occur, the competencies in question must be well rehearsed - to the point of automaticity - in a L1. Second, transfer is not likely to cease at any given point in time during L2 development. Third, the transferred competencies will continue to mature through experience with L2 print input” (pp. 17-18).

Grabe (2009) highlights the complexity of second language reading comprehension by describing the many differences between native and second language reading contexts. He suggests that between first and second language reading there can be:

(1) linguistic and processing differences (differing amounts of lexical, grammatical, and discourse knowledge at initial stages of L1 and L2 reading; greater metalinguistic and metacognitive awareness in L2 settings; varying linguistic differences across any two languages; varying L2 proficiencies as a foundation for L2 reading; varying language transfer influences; interacting influence of working with two languages); 
(2) individual and experiential differences (differing levels of L1 reading abilities; differing motivations for reading in the L2; differing amounts of exposure to L2 reading; differing kinds of texts in L2 contexts; differing language resources for $\mathrm{L} 2$ readers);

(3) sociocultural and institutional differences (differing sociocultural backgrounds of L2 readers; differing ways of organizing discourse and texts; differing expectations of L2 educational institutions) (p. 55).

He also concludes that "current L2 research suggests that the L2 reader is one who incorporates both L1 and L2 language and literacy knowledge" (p. 56).

In this study, we propose to examine students' native and foreign language reading literacy, following the guidelines formulated in the PISA, which defines reading literacy as "understanding, using, evaluating, reflecting on and engaging with texts in order to achieve one's goals, to develop one's knowledge and potential and to participate in society" (OECD 2018: 8). Accordingly, we chose to examine three main cognitive processes defined by the PISA reading literacy framework: locating information, understanding, evaluating and reflecting (OECD 2018: 3-4).

\section{Problem solving and reading}

Problem solving and reading literacy can be regarded as interdependent skills concerning tasks and situations which involve work with written texts and their interpretation both in one's native and second/foreign language. Reading can be regarded as the product of a complex combination of knowledge, skills, and various problem-solving strategies. Therefore, we believe that students with more developed problem-solving skills can comprehend texts more easily.

Although there are many interpretations, definitions, and theoretical models of problem solving in the literature, they share a common definition of the problem: there is a gap between the initial and target states, i.e. the path to achieving the target state is unknown. First, the problem has to be identified, and then possible solutions are searched for (Mayer-Wittrock 1996). Measuring the level of problemsolving skills is not new; it is one of the most widely researched thinking abilities in the dynamically developing world of the last two decades. Its development has been part of a number of educational and assessment programmes (e.g. OECD PISA measurements).

Pólya's (1957) model is one of the most popular process models for problem solving, and it also served as a basis for the PISA measurements. Based on this, the first step in solving the task is to interpret the text of the task. We need to recognize what we know and what we are looking for. After that, the problem has to be formulated, and a plan has to be prepared to solve it; then the right strategy has to be chosen, the task has to be solved, the correct solution is interpreted, 
and the validity of the solution is verified. As a final step, it is also important to communicate the result in an intelligible form. According to Pólya (2010), the most typical human activity is problem solving - purposeful thinking, searching for tools to achieve a goal.

The definition of problem solving given by the PISA 2003 Assessment Framework states that: "Problem solving is an individual's capacity to use cognitive processes to confront and resolve real, cross-disciplinary situations where the solution path is not immediately obvious and where the literacy domains or curricula areas that might be applicable are not within a single domain of mathematics, science or reading” (OECD 2003: 156). As this definition highlights it, problem solving is a complex skill, involving various cognitive processes and interdisciplinary background knowledge. Focusing on the development, problem-solving skills have become more important in secondary education in the last few years.

\section{Translation as a problem-solving activity}

The efficiency of translators' work is highly influenced not only by their language proficiency skills (reading, writing, listening, and speaking) but also by their problem-solving skills.

Put as plainly as possible, translation is problem-solving. The overriding problem is to get a text from one language to another. Theoretically, this can never be done. Practically it happens all the time. The translator with talent equal to his task need only be patient and resourceful, ignoring the detractors while working on his problems. As long as we remember at the outset that every text will present specific problems, we can still identify general problems - or problem areas - for which each text will present variations. (Rose, 1979)

In the process of translation, various difficulties and obstacles may arise, which require decision making and problem solving. As Wilss (1994) suggests, the boundary between problem solving and decision making in translation is unclear, and hence they cannot be separated from each other. Whenever a problem occurs, different translation strategies are activated in order to solve them. There have been several attempts to describe and categorize problem-solving strategies in translation.

Wilss (1996), for instance, approaches the question of problem-solving strategies from a cognitive perspective and describes what can happen when translators have to make choices and decisions in order to solve different problems in their work. He defines six stages that can occur in a decision-making process: 
(1) identification of the problem,

(2) clarification or description of the problem,

(3) researching and collecting background information,

(4) deliberation on how to proceed - pre-choice behaviour,

(5) moment of choice, and

(6) post-choice behaviour - evaluation of translation results.

But he also admits that problem solving and decision making may not be such a clearly constructed process in reality and practice, and several factors may interfere with these stages.

There may be obstructions at (almost) any stage that may halt or delay the decision-making procedure. What if a problem is not (sufficiently) clarified in Stage 2? How much information collection is required in Stage 3 before the translator dares to proceed further? What determines the length of deliberation in Stage 4; when and why does a translator stop these deliberations? And, what if there is no choice at Stage 5? What if it turns out in Stage 6 that a wrong move has been made? (Wilss 1996: 188)

Because of the complexity of problem-solving strategies in translation, this can be the topic of a following study; here we have only focused on possible connections regarding reading comprehension in native and foreign language, problem solving, and translation.

\section{Instruments of assessment}

Reading literacy in native and foreign language were examined focusing on three main cognitive processes inspired by the PISA reading literacy framework: locating information (accessing and retrieving information within a text), understanding (representing literal meaning, integrating and generating inferences), evaluating and reflecting (assessing quality and credibility, reflecting on content and form; cf. OECD 2018). However, we would like to note that we did not use any tasks designed for the PISA assessments, and we did not work with multiple texts. Items in the tasks always referred to one text.

When designing the tasks, we took in consideration what our target group studied at school, especially in the tasks testing reading literacy in native and foreign language. Regarding their native language, they studied Hungarian language and literature, meaning that they read, discussed, and analysed texts selected from Hungarian literature (novels, short stories, poems) according to the school curriculum. However, their foreign language studies did not include literary studies; instead they developed their reading skills mainly with the help of texts related to various 
everyday topics, belonging to different genres (such as articles from newspapers, magazines and the online media, brochures, letters, and sometimes fragments from literary works as well), and chosen and written for language teaching purposes.

The tasks testing reading literacy in foreign language were designed for our specific group, translation and interpretation trainees (most of them also teacher trainees), while the tasks measuring reading literacy in native language and problem solving had been developed and used in the assessment of a larger target population which also included part of our target group (Pletl 2019).

Reading literacy in native language was tested with the help of a short story, Házi dolgozat (Assignment), written by Hungarian author Dezső Kosztolányi. After reading the text, students had to answer 15 questions. The related items were grouped according to the cognitive processes as follows: locating information, understanding, evaluating and reflecting, and each of them were assessed with 5 items. The total score was 100 points, including 23 points for locating information, 33 points for understanding, and 44 points for evaluation and reflection.

Reading literacy in foreign language was tested with the help of two texts and tasks corresponding to the expected language performance level of the group (B2-C1). Each cognitive process (locating information; understanding; evaluating and reflecting) was measured with the help of five items. For locating information, they had to read a text and answer five multiple-choice questions. For understanding, evaluating and reflecting, they had to answer ten questions based on a given text. The maximum score achievable for this task was 100 points, including 40 points for the items measuring information location, 30 points for the items measuring understanding, and 30 points for the items measuring evaluating and reflecting processes.

The assessment of the level of problem solving was also built on the theoretical framework of the PISA research, which means that one of the tools for examining applicable knowledge is when students solve problems that are based on a lifelike situation. The solution of the task required the implementation of the same cognitive processes as the solution of the native and foreign language literacy assessment tasks.

The task presented a novel problem for the students, but their solution did not require complex mathematical thinking. When choosing the task, we started from the fact that in everyday situations we constantly meet situations that require logical ordering. For example, when dressing up, the socks and the trousers are put on sooner than the shoes. But the order does not matter in the case of the socks and trousers. Accordingly, the task depicted a series of unique actions within the framework of an event in a graphical form. The actions shown in the figure were linked by arrows indicating their sequence. An arrow from one action to another meant that the first had to happen before the second, but an action 
could be followed by several others. Several possible sequences could be formed from the first to the last possible action.

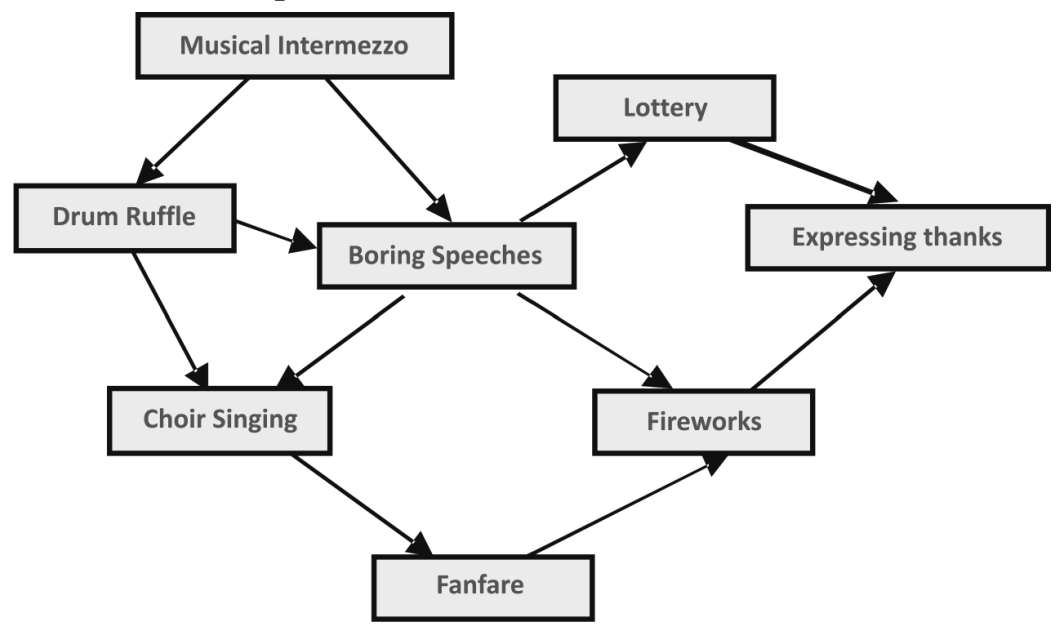

Figure 1. Problem-solving task

The problem-solving ability of the students was measured by a series of questions consisting of 20 items: locating information with 10 items, understanding with 6 items, and the evaluating and reflecting with 4 items. The maximum score achievable for this exercise was 100 points, including 35 points for the items measuring information location, 35 points for the items measuring understanding, and 30 points for the items measuring evaluating and reflecting processes.

In this study, students' translation skills were not assessed based on the three cognitive processes (locate information, understand, evaluate and reflect) followed in measuring the three other skills, mainly because - as we have pointed it out previously - translation is an especially complex problem-solving process which in fact includes the previous three examined skills. Problem-solving and cognitive processes involved in translation may be the topic of a further research. Here we only focused on possible correlations between reading comprehension in native and foreign language, problem solving, and translation. For this purpose, we assessed students' translation skills with a translation task consisting of translating two short texts (of approximately 150 words each) from English into Hungarian and two of the same length from Hungarian into English. The translations were evaluated considering the following criteria: correct transfer of information from the source text; appropriate choice of vocabulary and style in the target language; appropriate use of grammar, spelling, punctuation, and syntax. The maximum score achievable for translation was 100 points -25 points for each translated text. 


\section{The results of the survey}

42 first-year translation and interpretation students were assessed in the first semesters of two consecutive academic years (2017/18, 2018/19), in two steps: 2 hours were given for reading comprehension in foreign language and translation and 2 hours for reading comprehension in native language and problem solving.

\subsection{Reading literacy in native language}

In the items related to locating information, students had to find, select, and collect information from the text. The degree of difficulty of the operations depended on the amount of information to be retrieved, the form of the information (explicit or implicit), and the complexity of the text.

\section{Example:}

Question: Milyen esemény áll a történet középpontjában? 'What is the main event in the story?'

Correct answer/key: Egy házi dolgozat vagy fogalmazás megírása. 'Writing an assignment, a composition.'

Example for unacceptable answer: Egy hazugság. 'A lie.'

At this level, the success rate of students' performance was of $84.00 \%$.

In the items related to understanding, students had to interpret the text in order to attribute meaning. They had to draw conclusions from one or more parts of the text. The factors shaping the difficulty of the operations were the recognition of more hidden relations, the presence of idiomatic expressions requiring deeper understanding, and the length and complexity of the text.

Example:

Question/task: Jellemezd Palit a szöveg alapján. 'Characterize Pali based on the text.'

Correct answer/key: Pali tizenkét éves, harmadik gimnazista. Értelmes fiú, kitûnő tanuló, korát meghaladó tudással, látókörrel. 'Pali is a twelveyear-old third-grader. He is an intelligent boy, an excellent student, with knowledge and horizons beyond his age.'

Example for unacceptable answer: Pali okos, de lusta, rendetlen, nem szeret tanulni. 'Pali is clever but lazy, messy, he doesn't like to learn.'

At this level, the students' performance was of $69.26 \%$.

In the items related to reflection and evaluation, students had to establish a link between the text and their previous knowledge and experience. The 
difficulty of the operation was determined by the complexity of the text, students' background knowledge related to the text, and their thinking strategies. In these items, students often gave only partially correct or incomplete answers.

Example:

Question: A házi dolgozat értelmezhetó-e az alkotási folyamat metaforájaként? Válaszodat indokold! 'Can the assignment be interpreted as a metaphor for the creative process? Justify your answer!'

Correct answer/key: Értelmezhető az alkotási folyamat metaforájaként. $A z$ indoklás két szövegrészre is épülhet. (1.) Pali jellemzésére alkalmazott hasonlat: Arca zavart (...), mint egy elborult lángelméé, aki az alkotás gyötrelmében hánykolódik. (2.) Az író reflexiói: „Ha most Pali meg tudná írni, ami valóban benne él, ô lenne a világ legnagyobb írója.” mondattal kezdôdô rész. 'It can be interpreted as a metaphor for the creative process. The justification may be based on two passages. (1.) A simile used in Pali's characterization: His face is confused (...) as that of an overwhelmed genius, tumbling through the agony of creation. (2.) Reflections of the writer: "If Pali could now write what really lives in him, he would be the greatest writer in the world."

Example for unacceptable answer: Nem értelmezhetó, mert nem Pali írta meg a fogalmazást. 'Not applicable because the assignment was not written by Pali.'

At this level, the students' performance was of $52.41 \%$.

The following table summarizes the students' averages based on the three cognitive processes:

Table 1. Reading literacy in the native language - Students' averages

\begin{tabular}{lccc}
\hline & $\begin{array}{c}\text { Locate } \\
\text { information }\end{array}$ & Understand & $\begin{array}{c}\text { Evaluate and } \\
\text { reflect }\end{array}$ \\
\hline Maximum score & 23 & 33 & 44 \\
\hline Students' averages & 19.32 & 22.85 & 23.06 \\
\hline Students' averages in \% & 84.00 & 69.26 & 52.41 \\
\hline
\end{tabular}

The averages achieved by the students are lower than their averages in foreign language reading literacy. Their performance can be classified as high in locating information because $84 \%$ of them managed to find the required independent information in different parts of the text. In understanding, the measured results were slightly weaker, with more than two-thirds able to represent literal meaning or integrate and generate inferences within the text. In evaluation and reflection, it became more difficult to perform thinking operations, which required moving 
away from the text, forming opinions, and connecting the information with their own background knowledge; thus, the scores achieved were lower. The more abstract wording of the questions and the necessary background knowledge related to literature were the reasons why the tasks measuring reading literacy in native language proved to be more difficult than the tasks assessing skills related to the other two domains. It proved to be challenging to design tasks of similar difficulty level because students face different difficulties when reading in their native language and when reading in a foreign language due to the difference between the expected language performance level in their native language (normally C2) and in foreign language (ideally B2) but also their background knowledge and the nature of their previous studies.

\subsection{Reading literacy in foreign language}

In the items related to locating information, students had to find, select, and collect information from the text. The degree of difficulty of the operations depended on the amount of information to be retrieved, the form of the information (explicit or implicit), and the complexity of the text.

Example:

Question: Where can you have wild animals witnessing your wedding?

Sample answer/key: Masai Mara, Kenya.

Example for unacceptable answer: Banff, Canada.

At this level, the students' success rate was of $88 \%$.

In order to attribute meaning, students had to interpret the text in the items related to understanding. They had to draw conclusions from one or more parts of the text. The factors shaping the difficulty of the operations were the recognition of more hidden relations, the presence of idiomatic expressions requiring deeper understanding, and the length and complexity of the text.

Example:

Question: How does Aswany's work change our understanding of Egyptian society?

Sample answer/key: It reveals more information about the Egyptian society. / It gives an amazing picture of the Egyptian society, embracing its various layers.

Example for unacceptable answer: He writes about people's secret desires. At this level, the students' success rate was of $81.9 \%$. 
In the items related to reflection and evaluation, students had to establish a link between the text and their previous knowledge and experience. The difficulty of the operation was determined by the complexity of the text, students' background knowledge related to the text, and their thinking strategies. In these items, students often gave only partially correct or incomplete answers.

\section{Example:}

Question: Why is it important for a writer to "stay connected" to the street? Explain it starting from Aswany's example.

Sample answer/key: The street made Aswany successful. By keeping his job as a dentist, he has the possibility to watch what is happening in the street. If writers want constant inspiration and an inexhaustible source for ideas, it may be a good idea to stay connected to everyday life, talk to people, not to get separated from the street, which may always give them new ideas and inspiration.

Example for unacceptable answer: To make influential friends.

At this level, the students' success rate was of $57.6 \%$.

The following table summarizes the students' averages based on the three cognitive processes.

Table 2. Reading literacy in foreign language - Students' averages

\begin{tabular}{lccc}
\hline & $\begin{array}{c}\text { Locate } \\
\text { information }\end{array}$ & Understand & $\begin{array}{c}\text { Evaluate and } \\
\text { reflect }\end{array}$ \\
\hline Maximum score & 40 & 30 & 30 \\
\hline Students' averages & 35.52 & 24.57 & 17.28 \\
\hline Students' averages in \% & $88.8 \%$ & $80 \%$ & $57.6 \%$ \\
\hline
\end{tabular}

It is noticeable that the averages achieved by the students are higher than their averages in native language reading literacy but close to their averages in problem solving. Their performance can be classified as high in locating information because nearly $90 \%$ of them managed to find the required independent information in different parts of the text. In understanding, the measured results are also good, above $80 \%$ being able to represent literal meaning or integrate and generate inferences within the text. As for evaluation and reflection, it became more difficult to perform thinking operations which required moving away from the text, forming opinions, and connecting the information with their own background knowledge; thus, the scores achieved were well below the previous two levels but may also be considered satisfactory, approaching $60 \%$. One possible explanation of the high success rate may be that in previous years these students worked hard to develop their reading comprehension in English, and for this 
purpose they solved plenty of reading comprehension exercises, and so they had routine and experience in dealing with such types of tasks. Another explanation may be that the two texts they had to read were not literary works but B2- and C1-level texts selected from standardized English reading comprehension tests.

\subsection{Problem solving}

Regarding the problem-solving tasks, our previous research has shown that the more unusual or novel is the context of a task, the more students reject to solve it (Harangus 2018). So, the fact that in our survey $100 \%$ of the students tried to solve the problem-solving task shows that we had managed to design it to be motivating and interesting enough.

Taking into account the rules in the figure attached to the task, the first 10 items measured whether the students recognize the start and end points of the event sequence and can determine how many other events can precede or follow each event. The solution of the subtasks required the execution of the locate information cognitive process: the graphical representation of the task placed into context had to be recognized, interpreted, the data had to be identified according to the figure, and the relationships between them were determined. $90 \%$ of the students were able to correctly identify the information and identify and interpret the problem situations that can be directly understood from the figure, following the path defined by the arrows connecting the events.

In the subtasks that required the utilization of the cognitive process of understanding, the students performed less successfully. $73 \%$ of them were able to deduce from the directions in the figure the minimum number of actions that can make up any event, but only $54 \%$ were able to say how many different events could be organized. Students had trouble developing a strategy for complex problem scenarios that could lead to the right solution.

In the last subtask, a new action had to be inserted between two existing events, and so four new short events could be organized taking into account the new figure. The task requiring evaluation and reflection assumed the design and development of a multi-step strategy; students had to follow it in order to solve the problem. Almost one third of the students (27\%) did not even start this subtask, $55 \%$ did not understand the task properly, and only $18 \%$ were able to find a solution to the complex problem situation.

Table 3 shows the average scores achieved by students according to the cognitive processes. 
Table 3. Problem solving - Students' averages

\begin{tabular}{lccc}
\hline & $\begin{array}{c}\text { Locate } \\
\text { information }\end{array}$ & Understand & $\begin{array}{c}\text { Evaluate and } \\
\text { reflect }\end{array}$ \\
\hline Maximum score & 40 & 35 & 25 \\
\hline Students' averages & 36.14 & 24.55 & 4.55 \\
\hline Students' averages in \% & 90.35 & $70.17 \%$ & 18.2 \\
\hline
\end{tabular}

It is noticeable that from the three examined cognitive processes the students performed best in locating information. This is followed by the results in understanding, where a little more than two-thirds could interpret and apply data based on different forms of presentation and then create arguments based on them. In the third area of thinking, at the level of evaluation and reflection, it was more difficult to perform the tasks; therefore, the scores were well below the average.

\subsection{Translation}

In the translation task, the majority of the students (86\%) performed better when translating from English (a foreign language) into their native language, which is a natural and widely accepted tendency. A few students $(9.52 \%)$ were awarded the maximum 100 points, but there were other acceptable translations (45.23\%) awarded with $80,85,90$, or 95 points, without considerable misinterpretations of the source text. Therefore, it can be said that $54.76 \%$ of the students produced acceptable translations. Works awarded only with $60,65,70$, or 75 points $(33.3 \%)$ contained misinterpretations of phrases or sentences, which affected the overall meaning of the passage. One student $(2.38 \%)$ received 55 points for producing unacceptable translations containing several misinterpreted phrases and sentences, which significantly altered the overall message and meaning of the target text.

\subsection{Correlations}

Moderate correlation was found between reading literacy in native and foreign language $(r=0.521)$, native language literacy and translation $(r=0.636)$, and native language literacy and problem solving $(\mathrm{r}=0.573)$. Strong correlation was found between reading literacy in foreign language and problem solving $(\mathrm{r}$ $=0.775)$, reading literacy in foreign language and translation $(r=0.851)$, and translation and problem solving $(\mathrm{r}=0.858)$. 


\section{Conclusions}

With its interdisciplinary approach, this study concentrates on revealing the overlaps and meeting points, the spaces in between the use of translator trainees' native and foreign language reading skills, problem-solving abilities, and translation performance. The first three of these skills were evaluated on a three-level scale based on the three cognitive processes used in PISA assessments (location of information, understanding, evaluation and reflection) (OECD 2018).

Regarding native language reading literacy, the averages achieved by the students in this assessment were lower than their averages in foreign language reading literacy and problem solving. Obviously, this does not mean that in everyday life they would understand and interpret texts (for example, newspaper articles, user's guides, or a letter from a friend) better in a foreign language than in their native language. However, when planning this assessment, we tried to take in consideration what our target group had studied and practised in their school years. We did not expect that the sometimes more abstract wording of the questions, the fact that the text was a short story and that the answers required background knowledge related to literature would result in a lower success rate.

Regarding foreign language reading literacy, the averages achieved by the students were high, which may be due to the fact that in previous years our students worked hard to develop their reading comprehension in English. In their school years, they solved a large number of reading comprehension exercises, so they have considerable routine and experience in solving such types of tasks. The two texts they had to work with in this assessment were not literary works as in the native language reading literacy task but B2 level texts selected from standardized language tests.

Regarding problem-solving skills, the students performed best in locating information, closely followed by the success rate in understanding. At the level of evaluation and reflection, they had more difficulties to solve the tasks; therefore, the scores were below the average.

Moderate correlation was found between reading literacy in native and foreign language, native language literacy and translation, native language literacy and problem solving, and strong correlation between reading literacy in foreign language and problem solving, reading literacy in foreign language and translation, translation and problem solving, what demonstrates the interrelatedness of these skills.

The results of this study are relevant mainly to our target group, as part of a needs analysis, and we would like to use them as a starting point in curriculum development - for example, focusing more on developing the skills of evaluation and reflection in order to increase our students' chances on the labour market as future translators or language teachers. 


\section{References}

Alderson, Clark. 2000. Assessing reading. Cambridge: Cambridge University Press.

Brevik, Lisbeth M.-Olsen, Rolf Vegar-Hellekjær, Glenn Ole. 2016. The complexity of second language reading: Investigating the L1-L2 relationship. Reading in a Foreign Language 28(2): 161-182.

Grabe, William. 2009. Reading in a second language. Moving from theory to practice. Cambridge: Cambridge University Press.

Harangus, Katalin. 2018. A problémamegoldó képesség vizsgálata tanárképzős hallgatók körében [Examining problem-solving skills among teacher trainees]. In: Pletl, Rita (ed.), Anyanyelvoktatás. Új kihívások - a tudás fogalmának változása [Native language education. New challenges - Changes of the concept of knowledge]. Cluj-Napoca: Ábel. 70-85.

Mayer, Richard. E.-Wittrock, Merlin. C. 1996. Problem-solving transfer. In: Berliner, D. C.-Calfee, R. C. (eds), Handbook of educational psychology. New York: Macmillan. 47-62.

Pletl, Rita. 2019. A problémamegoldó képesség országos hatókörű vizsgálata. A kutatás elméleti, tudományos háttere, metodológiája [Examination of problemsolving ability on a national scale. Theoretical, scientific background and methodology of the research]. In: Pletl, Rita (ed.), Anyanyelvoktatás [Native language education]. Cluj-Napoca: Ábel. 8-22.

Pólya, György.1957. How to solve it. Garden City, NY: Doubleday. 2010. A problémamegoldás iskolája [The school of problem solving]. Budapest: Typotex.

Wilss, Wolfram. 1996. Knowledge and skills in translator behaviour. Amsterdam: John Benjamins.

\section{Web sources}

Brisbois, Judith E. 1995. Connections between first- and second-language reading. Journal of Reading Behavior 27(4): 565-584. https://journals.sagepub.com/ doi/abs/10.1080/10862969509547899 (downloaded on: 7 April 2019).

Cummins, James. 1979. Linguistic interdependence and the educational development of bilingual children. Bilingual Education Paper Series 3(2). https://files.eric.ed.gov/fulltext/ED257312.pdf (downloaded on: 7 April 2019). Jiang, Xiangying. 2011. The role of first language literacy and second language proficiency in second language reading comprehension. The Reading Matrix 11(2): 17-190. http://www.readingmatrix.com/articles/april_2011/jiang.pdf (downloaded on: 7 April 2019). 
Koda, Keiko. 2007. Reading and language learning: Crosslinguistic constraints on second language reading development. Language Learning 57(Suppl. 1): 1-44 https://www.researchgate.net/publication/229460119_Reading_and_ Language_Learning_Crosslinguistic_Constraints_on_Second_Language_ Reading_Development (downloaded on: 7 April 2019).

Mátyás, Judit. 2010. Idegen nyelvü szövegek értelmezése az anyanyelvi olvasási tapasztalatok tükrében [Interpreting foreign language texts in the light of experience in native language reading]. http://www.anyanyelv-pedagogia.hu/ cikkek.php?id=271 (downloaded on: 7 April 2019).

OECD. 2003. The PISA 2003 Assessment framework - Mathematics, reading, science and problem solving knowledge and skills. http://www.oecd. org/education/school/programmeforinternationalstudentassessmentpisa/ 33694881.pdf (downloaded on: 7 April 2019).

2018. PISA 2018 Reading literacy framework. https://www.oecd.org/pisa/data/ PISA-2018-draft-frameworks.pdf (downloaded on: 7 April 2019).

Rose, Marilyn Gaddis. 1979. Translation as problem-solving. Translation Review 3(1): 20-21. https://www.tandfonline.com/doi/abs/10.1080/07374836.1979.10 523556 (downloaded on: 7 April 2019).

Wilss, Wolfram. 1994. A framework for decision-making in translation. Target. International Journal of Translation Studies 6(2): 131-150. https://benjamins. com/catalog/target.6.2.02wil (downloaded on: 7 April 2019).

Yamashita, Junko. 2002. Mutual compensation between L1 reading ability and L2 language proficiency in L2 reading comprehension. Journal of Research in Reading 25: 81-95. https://onlinelibrary.wiley.com/doi/abs/10.1111/14679817.00160 (downloaded on: 7 April 2019). 